\title{
Kurva Pertambahan Bobot Badan Domba Garut Jantan Umur 13-16 Bulan yang Diberi Ransum pada Imbangan $60 \%$ Hijauan dan $40 \%$ Konsentrat
}

\author{
Average Daily Gain Curve of 13-16 Months Old Male Garut Sheep Fed Ration with 60\% \\ Forage and $40 \%$ Concentrate
}

\author{
R. N. Rachman', D. Rahmat' ${ }^{1}$ B. Ayuningsih ${ }^{1}$, F. T. Santoso ${ }^{2}$, T. Dhalika ${ }^{1}$ \& I. Hernaman ${ }^{*}$ \\ ${ }^{1}$ Fakultas Peternakan Universitas Padjadjaran, Sumedang, 45363 \\ ${ }^{2}$ Unit Pelaksan Teknis Dinas (UPTD) Balai Pengembangan dan Perbibitan Ternak Domba dan Kambing \\ (BPPTDK) Margawati, Garut, 44113 \\ *Email korespondensi: iman_hernaman@yahoo.com
}

\author{
- Diterima: 18 Juni 2021 • Direvisi: 05 Agustus 2021 • Disetujui: 23 Agustus 2021
}

\begin{abstract}
ABSTRAK. Penelitian bertujuan untuk mengetahui kurva pertambahan bobot badan domba Garut jantan umur 13-16 bulan yang diberi ransum pada imbangan $60 \%$ hijauan dan $40 \%$ konsentrat. Penelitian menggunakan metode penelitian korelasional. Ternak yang digunakan pada penelitian ini sebanyak 8 ekor. Data yang diperoleh dianalisis menggunakan Curve Expert. Hasil penelitian menunjukan bahwa kurva pertambahan bobot badan domba Garut jantan umur 13-16 bulan relatif menurun dan masuk ke fase pertumbuhan lambat dengan model kurva terbaik untuk kurva pertambahan bobot badan yakni model Polynomial pada persamaan $y=81,676+6,612 x+\left(-2,062 x^{2}\right)+0,201 x^{3}+\left(-0,00669 x^{4}\right)$ dengan nilai standar error (SE) 0,498, koefisien korelasi (r) 0,997 dan koefisien determinasi ( $\left.\mathrm{R}^{2}\right)$ 0,994.
\end{abstract}

Kata kunci: Domba Garut jantan, kurva pertambahan bobot badan, ransum.

ABSTRACT. The aim of this study was to determine the average daily gain (ADG) curve of male Garut sheep aged 13-16 months which were given rations at a $60 \%$ forage and $40 \%$ concentrate. The study uses correlational research methods. There were 8 sheeps used in this study. The data obtained were analyzed using Curve Expert. The results showed that the ADG curve of 13-16 months old male Garut sheep relatively decreased and entered the slow growth phase with the best curve model for the ADG curve was the Polynomial model in the equation $Y=81.676+6.612 X+\left(-2.062 X^{2}\right)+0.201 X^{3}\left(-0.00669 X^{4}\right)$ with a standard error value (SE) 0.498 , a correlation coefficient ( $r) 0.997$ and a coefficient of determination $\left(R^{2}\right) 0.994$.

Keywords : Male Garut sheep, average daily gain curve, ration.

\section{PENDAHULUAN}

Domba Garut merupakan salah satu jenis domba lokal dengan potensi genetik yang baik. Dalam pertumbuhan domba Garut terdapat beberapa faktor penting yang dapat memengaruhinya, diantaranya adalah pakan. Pakan yang diberikan harus memiliki kualitas yang tinggi, yaitu mengandung nutrien yang dibutuhkan oleh tubuh ternak dalam kehidupannya seperti protein, lemak, karbohidrat, mineral, dan air. Jumlah kebutuhan nutrien setiap harinya bergantung pada umur, jenis ternak, umur, dan fase pertumbuhannya meliputi fase anak, fase dewasa, fase bunting dan fase menyusui). Setiap ekor ternak yang berbeda kondisinya membutuhkan nutrien yang berbeda (Dhuhitta et al., 2014).

Pakan domba yang diberikan biasanya terdiri atas hijauan dan makanan tambahan berupa konsentrat. Hijauan merupakan pakan utama sebagai sumber energi utama untuk ternak ruminansia yang mengandung serat kasar tinggi. Hijauan jenis rerumputan mengandung protein kasar yang rendah, sehingga harus diberikan asupan pakan tambahan yang memiliki kualitas nutrien yang lebih unggul agar diperoleh imbangan nutrien yang sesuai kebutuhan ternak, yaitu dengan cara penambahan konsentrat dalam ransumnya. Penggunaan konsentrat sebanyak $40 \%$ pada ransum domba berbasis rumput lapangan 
menghasilkan respon paling baik terhadap domba Garut jantan dengan PBBH rata-rata sebesar 152,68 g/ekor/hari serta mempunyai konversi pakan yang lebih baik dibandingkan dengan perlakuan imbangan yang lainnya (Somanjaya et al., 2016). Hasil ini membuktikan bahwa pakan tambahan berupa konsentrat mampu meningkatkan performa, khususnya pertambahan bobot badan domba Garut jantan.

Pertambahan bobot badan atau pertumbuhan pada ternak terbagi dalam dua fase, yaitu fase sebelum dewasa kelamin dan fase setelah dewasa kelamin, pada fase sebelum dewasa kelamin ini merupakan fase pertumbuhan yang cepat, sedangkan pada fase setelah dewasa kelamin merupakan fase pertumbuhan yang mulai melambat dan mengalami titik infleksi dari laju pertumbuhan ternak. Pada domba Priangan atau domba Garut, laju pertumbuhan yang dimiliki lebih lambat dengan rentang waktu yang relatif lama dibandingkan dengan domba Eropa. Domba Priangan atau domba Garut masih menunjukkan adanya pertumbuhan sampai umur 24 bulan, sedangkan domba Eropa hanya sampai umur 18 bulan (Ilham, 2008).

Kurva pertumbuhan menunjukkan suatu kemampuan individu ternak dalam menampilkan potensi genetik yang dimilikinya serta perkembangan bagian-bagian tubuh sampai mencapai dewasa. Kurva regresi nonlinear yang dapat menggambarkan pertumbuhan pada ternak, diantaranya adalah model Logistic dan Gompertz (Salman et al., 2012), model Morgan Mercer Floden/MMF (Tariq et al., 2013), dan model Richards (Teleken et al., 2017). Model kurva Weibull (Putra et al., 2018), model kurva Polynomial (Bukhori et al., 2017) dan model kurva Heat Capacity juga dapat digunakan dalam menentukan kurva dalam pertambahan bobot badan.

Untuk mengetahui tingkat keakuratan dari model kurva non-linear, diperlukan perbandingan diantara model tersebut. Model matematik kurva pertumbuhan dapat memberikan manfaat sebagai parameter seleksi dan berguna untuk menganalisis performa ternak (Salman et al., 2012).

Penelitian kurva pertambahan bobot badan pada domba Garut jantan dengan jenis dan proporsi pakan yang digunakan perlu dilakukan untuk memilih replacement stock atau dijadikan bibit yang baik dengan melihat laju pertumbuhan dari setiap ternak pada umur 1316 bulan.

\section{MATERI DAN METODE}

Delapan ekor domba Garut jantan umur 13-16 bulan diberi pakan dengan imbangan 60\% hijauan dan $40 \%$ konsentrat (bahan kering) selama 12 minggu. Domba tersebut merupakan milik Unit Pelaksana Teknis Dinas (UPTD) Balai Pengembangan Perbibitan Ternak Domba dan Kambing (BPPTDK) Margawati, Kelurahan Sukanegla, Kecamatan Garut Kota, Kabupaten Garut, Jawa Barat. Rataan bobot badan awal penelitian sebesar 28,93 $\pm 2,06$ dengan koefisien variasi sebesar $7,22 \%$ dan nilai ini masih dianggap seragam karena di bawah 15\% (Kusmayadi dan Aryanto, 2018).

Bahan pakan yang digunakan berupa rumput Gajah var. Taiwan dan konsentrat. Hijauan berasal dari kebun rumput yang ditanam di UPTD-BPPTDK Margawati. Konsentrat merupakan hasil formulasi dari berbagai jenis pakan yang terdiri atas delapan jenis bahan baku yaitu bungkil kedelai, bungkil kelapa, jagung, dedak padi, pollard, mollases, mineral mix, dan onggok. Konsentrat merupakan pakan jadi yang dibeli dari perusahaan pakan yang berasal dari Bandung. Kandungan nutrien rumput Gajah var Taiwan dan Konsentrat tertera pada Tabel 1.

Setiap minggu diukur bobot badan sebagai bahan data untuk mengukur pertumbuhan. Model persamaan kurva pertumbuhan menggunakan model yang sering digunakan antara lain model Gompertz, Logistic, Richards, MMF, Weibull, Heat Capacity dan Polynomial 
Kurva Pertambahan Bobot Badan Domba Garut Jantan Umur 13-16 Bulan yang Diberi Ransum pada Imbangan 60\% Hijauan dan 40\% Konsentrat (Rachman, dkk.)

yang diolah dengan menggunakan program

Curve Expert. Model matematika kurva yang digunakan untuk analisis model pertambahan bobot badan tertera pada Tabel 2.

Tabel 1. Kandungan nutrien rumput Gajah Taiwan dan konsentrat

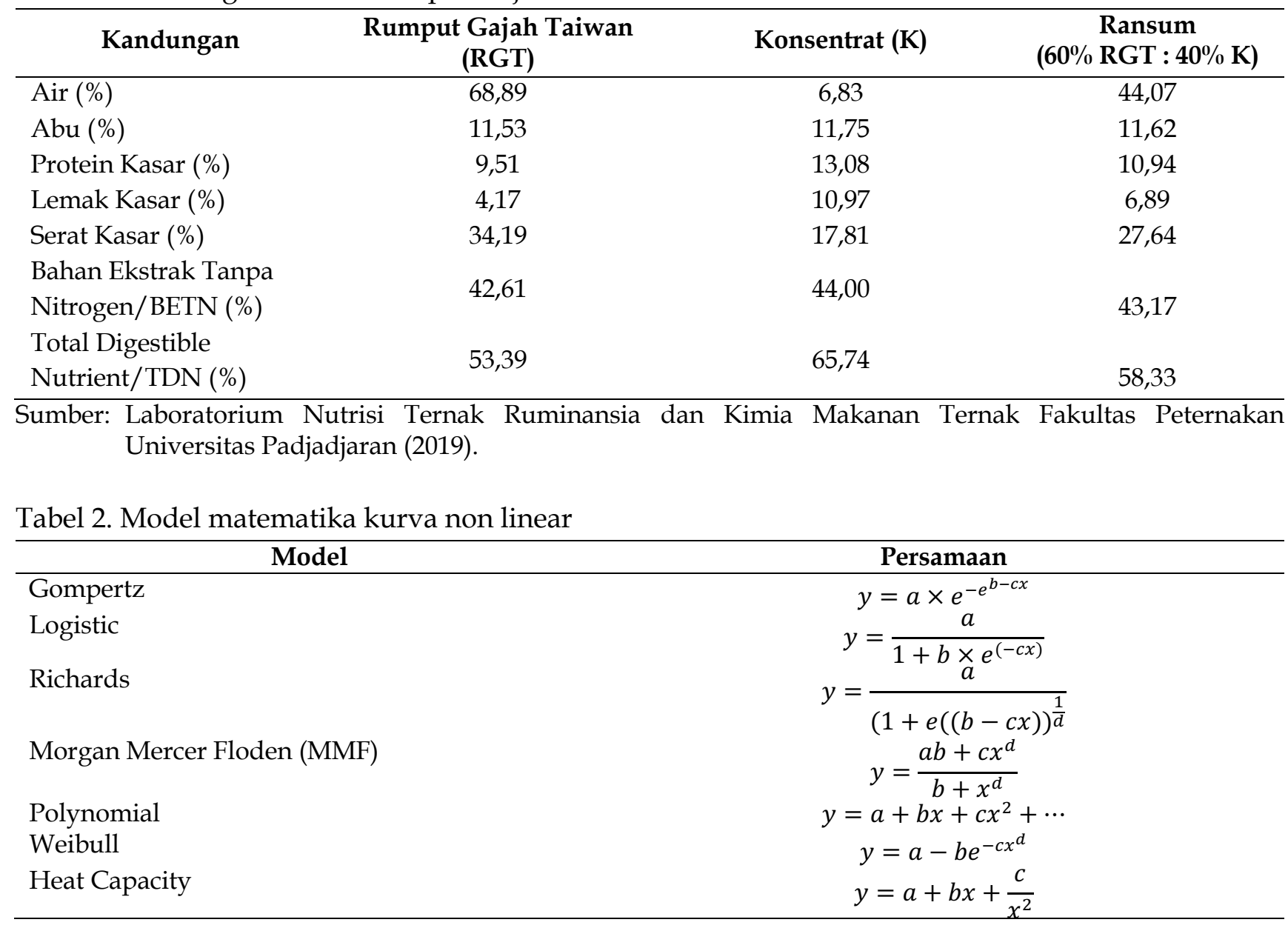

Model kurva terbaik ditentukan berdasarkan persamaan regresi yang memiliki koefisien determinasi $\left(\mathrm{R}^{2}\right)$ terbesar dengan standar error (SE) yang terkecil (Salman et al., 2012).

\section{HASIL DAN PEMBAHASAN}

Dalam pertumbuhan dan pertambahan bobot badan perlu dilakukan penimbangan bobot badan pada setiap minggunya. Rataan bobot badan selama 12 minggu pemeliharaan dapat dilihat pada Tabel 3.

Berdasarkan Tabel 3. menunjukan bahwa rataan bobot badan domba Garut jantan pada setiap minggunya mengalami kenaikan dengan rataan akhir setelah 12 minggu pemeliharaan sebesar 35,75 kg. Hasil ini menunjukkan bobot badan yang lebih besar bila dibandingkan dengan SNI 7532.1-2015 (2015), dimana standar bobot badan Domba Garut jantan pada rentang umur 12 - 18 adalah $33 \mathrm{~kg}$. Kemungkinan besar hal ini karena ransum yang diberikan memiliki kualitas yang tinggi karena mengandung konsentrat sebesar $40 \%$ dari bahan kering ransum dengan protein sebesar 13,08\%. Bobot badan merupakan hasil metabolisme dari ransum yang dikonsumsi ternak. Hal ini didukung dengan pendapat Usman et al., (2013) menyebutkan bahwa konsumsi ransum adalah faktor utama yang merupakan basis kehidupan dan menentukan performa produksi ternak ruminansia. 
Tabel 3. Rataan bobot badan domba Garut jantan umur 13-16 bulan pada imbangan pakan $60 \%$ hijauan dan $40 \%$ konsentrat

\begin{tabular}{cc}
\hline & Rata-Rata Bobot Badan (kg/ekor) \\
\hline Bobot Awal & $28,93 \pm 2,06$ \\
\hline Bobot minggu ke- & $29,54 \pm 1,94$ \\
2 & $30,15 \pm 1,83$ \\
3 & $30,77 \pm 1,82$ \\
4 & $31,38 \pm 1,86$ \\
5 & $31,96 \pm 1,95$ \\
6 & $32,53 \pm 1,93$ \\
7 & $33,10 \pm 1,98$ \\
8 & $33,65 \pm 2,10$ \\
9 & $34,18 \pm 2,09$ \\
10 & $34,71 \pm 2,10$ \\
11 & $35,24 \pm 2,14$ \\
12 & $35,75 \pm 2,10$ \\
\hline
\end{tabular}

Pertambahan bobot badan pada ternak adalah salah satu kriteria yang digunakan untuk mengukur pertumbuhan (Hernaman et al., 2018). Pertambahan bobot badan ini bisa dijadikan sebagai parameter untuk menentukan kecepatan pertumbuhan. Rataan pertambahan bobot badan mingguan selama 12 minggu dapat dilihat pada Tabel 4.

Tabel 4. Rataan pertambahan bobot badan harian domba Garut jantan umur 13-16 bulan pada imbangan pakan $60 \%$ hijauan dan $40 \%$ konsentrat

\begin{tabular}{cc}
\hline Minggu & Rata-rata Pertambahan Bobot Badan (g/ekor/hari) \\
\hline 1 & $86,61 \pm 27,91$ \\
2 & $87,50 \pm 27,47$ \\
3 & $88,39 \pm 20,18$ \\
4 & $86,61 \pm 28,17$ \\
5 & $83,93 \pm 38,89$ \\
6 & $81,25 \pm 42,68$ \\
7 & $80,36 \pm 16,97$ \\
8 & $78,57 \pm 24,15$ \\
9 & $76,79 \pm 20,82$ \\
10 & $75,89 \pm 20,18$ \\
11 & $75,00 \pm 8,54$ \\
12 & $73,21 \pm 13,63$ \\
Rataan & $81,17 \pm 24,88$ \\
\hline
\end{tabular}

Pertambahan bobot badan domba Garut jantan mengalami kenaikan di minggu awal pemeliharaan hingga minggu ke-3 dan mulai menurun di minggu ke-4 hingga minggu ke-12. Penurunan tersebut karena domba tersebut mulai diteliti pada rumur 13 bulan dan sudah melewati masa pubertas serta telah mendekati dewasa tubuh. Menurut Rusdiana dan Adiati
(2020), domba mengalami proses pertumbuhan yang cepat pada awal kehidupannya sampai pada masa pubertas, kemudian pertumbuhan tersebut akhirnya melambat pada saat domba mendekati dewasa tubuh. Pertambahan bobot badan paling tinggi berada di minggu ke-3 yaitu sebesar 637,50 g/minggu atau 88,39 g/hari. Rataan pertambahan bobot badan setiap 
ekornya berkisar 568,22 g/minggu atau 81,17 $\mathrm{g} /$ hari. Rataan tersebut menunjukkan lebih kecil jika dibandingkan dengan penelitian Somanjaya et al., (2016) menyatakan bahwa ransum percobaan yang menggunakan imbangan $60 \%$ rumput lapangan dan $40 \%$ konsentrat mendapatkan respon performa terbaik dari domba Garut jantan dengan pertambahan bobot badan harian rata-rata sebanyak 152,68 $\mathrm{g} /$ ekor/hari. Perbedaan ini diduga dipengaruhi oleh faktor lingkungan dan genetik, hal ini sesuai dengan pernyataan dari Wijaya et al., (2016) bahwa pertambahan bobot badan dipengaruhi oleh beberapa faktor antara lain total protein yang diperoleh setiap harinya, jenis ternak, umur, keadaan genetik, lingkungan, kondisi setiap individu dan manajemen tata laksana.
Hasil pengolahan data menunjukkan bahwa model kurva Gompertz, Logistic, Richards, dan MMF, tidak cocok dengan data yang tersedia, karena model ini hanya dapat digunakan untuk data pertambahan bobot badan yang meningkat, hal ini terbuki dengan perhitungan menggunakan Curve Expert yang menghasilkan nilai error. Oleh karena itu, model tersebut tidak dapat diperoleh persamaan matematikanya. Sementara itu, Model kurva Weibull, Heat Capacity dan Polynomial dapat dihitung dan lebih cocok dengan data yang diperoleh karena data menunjukan pertambahan bobot badan yang menurun (Tabel 4) dan hasilnya disajikan pada Tabel 5.

Tabel 5. Hasil analisis kurva pertambahan bobot badan harian domba Garut jantan umur 13-16 bulan pada imbangan pakan $60 \%$ Hijauan dan $40 \%$ Konsentrat

\begin{tabular}{ccccc}
\hline No. & Model & Persamaan & $\mathbf{R}^{2}$ & Standart Error \\
\hline \multirow{2}{*}{1} & Polynomial & $\begin{array}{c}\mathrm{y}=81,676+6,612 \mathrm{x} \\
+\left(-2,062 \mathrm{x}^{2}\right)+0,201 \mathrm{x}^{3} \\
+\left(-0,00669 \mathrm{x}^{4}\right)\end{array}$ & 0,994 & 0,498 \\
2 & Weibull & $\mathrm{y}=87,541-19,271 \mathrm{e}^{-36,338 \mathrm{x}^{-1,879}}$ & & \\
& & & 0,988 & 0,674 \\
3 & Heat Capacity & $\mathrm{y}=92,471+(-1,653 \mathrm{x})+\frac{-4,203}{\mathrm{x}^{2}}$ & 0,978 & 0,862 \\
\hline
\end{tabular}

Dari tabel di atas menunjukan ketiga model tersebut merupakan model kurva yang cocok untuk data yang diperoleh, serta model terbaik untuk kurva pertambahan bobot badan adalah model kurva Polynomial pada derajat 4 . Hal ini didasarkan pada nilai koefesien determinasi $\mathrm{R}^{2}$ yang paling tinggi dengan standart error (SE) terendah. Grafik kurva Polynomial tersebut disajikan pada Gambar 1.

Gambar 1., menunjukan bahwa kurva pertambahan bobot badan yang diperoleh relatif menurun dan masuk ke fase pertumbuhan yang melambat, hal ini disebabkan karena fase pertumbuhan yang menuju dewasa tubuh
(Rusdiana \& Adiati, 2020), yaitu umur 16 bulan. Persamaan kurva yang diperoleh adalah $\mathrm{y}=\mathrm{a}+$ $\mathrm{bx}+\mathrm{cx}^{2}+\mathrm{dx} \mathrm{x}^{3}+\mathrm{ex}^{4}$ dengan nilai $\mathrm{a}=81,676, \mathrm{~b}=$ $6,612, c=-2,062, d=0,201$, dan e $=-0,00669$. Keakuratan model kurva diamati berdasarkan standart error, koefisien korelasi (r) dan koefisien determinasi $\left(\mathrm{R}^{2}\right)$. Nilai standart error (SE) model kurva Polinomial sebesar 0,498, sedangkan koefisien korelasi ( $\mathrm{r}$ ) sebesar 0,997 serta koefisien determinasi $\left(R^{2}\right)$ sebesar 0,994. Nilai korelasi yang tinggi menunjukkan keakuratan antara dua variabel tersebut tinggi, sesuai pendapat Muizu et al., (2016) bahwa nilai koefisien korelasi (r) sangat kuat berkisar 0,76 0,99 . 


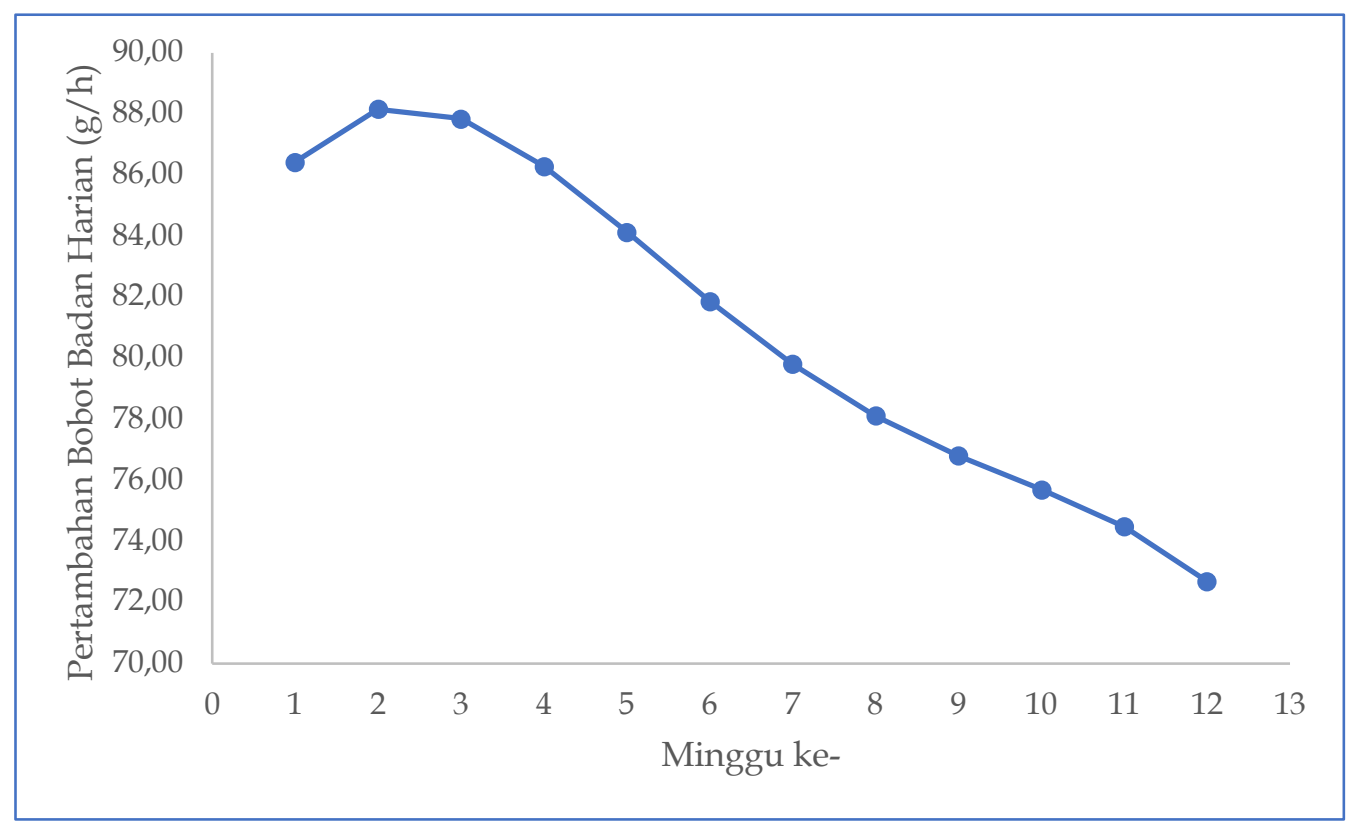

Gambar 1. Kurva polynomial pertambahan bobot badan domba Garut jantan umur 13-16 bulan pada imbangan pakan $60 \%$ hijauan dan $40 \%$ konsentrat.

\section{KESIMPULAN}

Kurva pertambahan bobot badan domba Garut jantan umur 13-16 bulan relatif menurun dan masuk pada fase pertumbuhan lambat dan model kurva terbaik untuk pertambahan bobot badan yaitu model Polynomial dengan persamaan $\mathrm{y}=81,676+6,612 \mathrm{x}+\left(-2,06 \mathrm{x}^{2}\right)+$ $0,201 x^{3}+\left(-0,00669 x^{4}\right)$ serta memiliki nilai standar error (SE) 0,498, koefisien korelasi (r) 0,997 dan koefisien determinasi $\left(R^{2}\right)$ 0,994.

\section{UCAPAN TERIMAKASIH}

Terimakasih disampaikan kepada UPTD Balai Pengembangan Perbibitan Ternak Domba dan Kambing Margawati, Dinas Ketahanan Pangan dan Peternakan Provinsi Jawa Barat atas fasilitas penelitian yang disediakan.

\section{KONFLIK INTERES}

Artikel ini didasarkan pada hasil penelitian dan tidak ada konflik kepentingan yang berhubungan dengan keuangan, pribadi, atau lainnya dengan orang atau organisasi lain yang terkait dengan materi yang dibahas dalam naskah.

\section{DAFTAR PUSTAKA}

Badan Standarisasi Nasional (BSN). 2015. SNI 7532.1:2015 Bibit Domba - Bagian 1: Garut. Badan Standarisasi Nasional. Jakarta.

Bukhori, I, R. Aka, \& T. Saili. 2017. Pola pertumbuhan kambing Kacang jantan di Kabupaten Konawe Selatan, Jurnal Ilmu dan Teknologi Peternakan Indonesia 4 (3) : 34-41.

Dhuhitta, A.M., S. Dartosukarno \& A. Purnomoadi. 2014. Pengaruh jumlah pakan yang berbeda terhadap kondisi fisiologi kambing Kacang. Animal Agriculture Journal 3(4): 569-574.

Hernaman, I., B. Ayuningsih, D. Ramdani, M. Maisarah, \& Siswoyo. 2018. Performance of female Garut lambs fed diet in different ratio of protein and total digestible nutrients. Jurnal Veteriner 19 (4) : 568-573.

Ilham, F. 2008. Karakteristik Pertumbuhan Pra dan Pascasapih Domba Lokal di Unit Pendidikan dan Penelitian Peternakan Jonggol Institut Pertanian Bogor (UP3J-IPB). Tesis. Sekolah Pascasarjana. Institut Pertanian Bogor. Bogor. 62. 
Kusmayadi, T \& R. Aryanto. 2018. Bobot badan dan ukuran tubuh sapi perah betina fries holland di wilayah Desa Cipangramatan Kecamatan Cikajang Kabupaten Garut. Jurnal Ilmu Peternakan (JANHUS), 3 (1): 29-38.

Muizu, W.O.Z, S.N. Evita \& D. Suherman. 2016. Disiplin kerja dan pengaruhnya terhadap kinerja pegawai negeri sipil. Pekbis Jurnal, 8 (3) : 172-182.

Putra, . W.P.B., Sumadi, T. Hartatik, \& H. Saumar. 2018. Pendugaan model kurva pertumbuhan berat badan pada Sapi Aceh (Bos indicus). Jurnal Ilmu dan Teknologi Peternakan Indonesia 4 (1): 166-171.

Rusdiana, S \& U. Adiati. 2020. Perbanyakan dan penyebaran bibit ternak domba compass agrinak mendukung perekonomian peternak. Jurnal Sain Peternakan Indonesia, 15 (1): 67-74.

Salman, L.B., R.R. Noor, A. Saefuddin \& C. Talib. 2012. Comparison on accuracy of logistic, gompertz and von bertalanffy models in predicting growth of new born calf until first mating of holstein Friesian heifers. J. Indonesian Trop. Anim. Agric. 37(3) : 151-160.
Somanjaya, R., U. I. L. Rahmah, \& U. Dani. 2016. Performa dan daya cerna domba Garut jantan terhadap penambahan fermentasi limbah hijauan sorgum ke dalam ransum. Jurnal Pertanian 2 (2): 147-162.

Tariq, M.M., F. Iqbal, E. Eyduran, M.A. Bajwa, Z.E. Huma \& A. Waheed. 2013. Comparison of nonlinear functions to describe the growth in Mengali sheep breed of Balochistan. Pakistan J. Zool. 45(3) 661-665.

Teleken, J.T., A.C. Galvão \& W.S. Robazza. 2017. Comparing non-linear mathematical models to describe growth of different animals. Acta Sci., Anim. Sci. 39 (1) 73-81.

Usman Y., E.M. Sari, \& N. Fadilla. 2013. Evaluasi pertambahan bobot badan sapi aceh jantan yang diberi imbangan antara hijauan dan konsentrat di Balai Pembibitan Ternak Unggul Indrapuri. Agripet 13 (2) : 41-46.

Wijaya, G.H., M. Yamin, H. Nuraini \& A. Esfandiari. 2016. Performans produksi dan profil metabolik darah domba Garut dan Jonggol yang diberi limbah tauge dan omega-3. Jurnal Veteriner 17 (2) : 246-256. 